\title{
The effect of bovine colostrum usage on serum immunoglobulins and protein levels in basketball players
}

\author{
Ali Osman KIVRAK¹, Gurkan UCAR² \\ ${ }^{1}$ School of Physical Education and Sports, University of Selcuk, Konya, Turkey. \\ ${ }^{2}$ Department of Food Hygiene and Technology, Faculty of Veterinary Medicine, University of Selcuk, Konya, Turkey. \\ * This study was summarized from doctorate thesis and presented as a poster at the $13^{\text {th }}$ International Sports Sciences Congress in Selcuk University \\ (7-9 November 2014). \\ Address correspondence to A.O. Kivrak, e-mail: aokivrak@selcuk.edu.tr
}

\begin{abstract}
This study was done to investigate the effect of bovine colostrum usage on serum immunoglobulins and protein levels in basketball players. 24 male basketball players from students at Physical Education and Sports in Selcuk University participated in this study. These players were divided into two groups including a control group of 12 persons and an experimental group of 12 persons. The sportsmen's blood samples were taken for the research three times (at 0th, 30th and 60th days), the serum immunoglobulins (IgG, IgA, IgM, IgE) and the proteins (Albumin, Globulin, Total Protein) were analyzed using standard methods. Moreover, the statistical analyses were done for the experimental and control groups in the basketball players with the SPSS 15 program and evaluated as well. When considered the results, it was determined that there were increases in the average amounts of Serum IgG, IgE, Globulin, Total Protein. However, a significant decrease was found in the Serum IgM. And it was found out that there were differences in the globulin amount and the total protein values $(\mathrm{P}<0.05)$ between the control and experimental groups using colostrum. In conclusion, it has been suggested that future researches on colostrum will be suitable for various sports branches and different age groups considering especially sportsmen' criteria such as immunity, regeneration, performance. Thus, the sportsmen will benefit from the outstanding characteristics of colostrum at a maximum level; the success will be achieved more in this way.
\end{abstract}

Keywords: Basketball, colostrum, immunoglobulin, protein.

\section{INTRODUCTION}

Colostrum is a secretion with high nutritional value which is produced by mammals shortly after birth, has a composition and an image different from normal milk, including a thick consistency, a yellowish color and a hot taste. Colostrum includes some biological active molecules necessary for immune and growth functions of body as well as protein, carbohydrates, fat, vitamins and minerals (4).

Bovine colostrum has important roles in efficient treatments of various diseases among persons. Its anti-oxidant and anti-aging characteristics help to overcome several problems age brings. Colostrum also supports recoveries from various mucosal, skin and muscle injuries (18).

Colostrum is so rich in nutrients; furthermore, it is known to involve many biologically active items effective on specific functions. For this reason, it is a foodstuff which protects health with its effects such as strengthening immune system, encouraging cell development and repairing tissues (11).

Many researchers who focused on the effect of colostrum on sportsmen in their studies, dealt with its effect on serum IGF-I, IgG, hormone and saliva IgA levels in athletes (14), and on IGF-I, IgG, IgA, saliva IgA in sportsmen (15), some of them analyzed its effect on serum immunoglobulins in cyclists and its effect on saliva IgA levels in marathon runners (9, 17). Researches were done to view the effect of colostrum on immunoglobulins and albumin amount in swimmers (10). It was stated that there were no statistically significant differences in serum $\operatorname{IgG}, \operatorname{Ig} \mathrm{A}, \mathrm{IgM}$ and IgE levels between placebo and colostrum groups using colostrum (7). Some studied on the effect of colostrum supplement on body composition and exercise performance in some sports branches, especially in oarsmen and cyclists $(2,5,6,8,12,16)$. Some tests were performed in a laboratory environment confirmed by International Olympics Committee among sportsmen who used 
the bovine colostrum during 4 weeks, these showed that there were not any forbidden agents used (13).

Within this study, it was aimed at the effect of bovine colostrum usage on serum immunoglobulins and protein levels in basketball players.

\section{MATERIAL \& METHODS}

\section{Research Group}

Among students at the School of Physical Education and Sports in Selcuk University, 24 male basketball players participated in this research. These players were divided into two groups: an experimental group of 12 persons and a control group of 12 ones.

While the basketball experimental group had averages of age $22.25 \pm 0.83$ years, height $189.48 \pm 2.69$ and body weight $86.29 \pm 4.51$, the basketball control group had averages of age $22.00 \pm 0.56$ years, height $181.50 \pm 2.44$ and body weight $72.27 \pm 3.30 \mathrm{~kg}$.

Before starting the measurements, the sportsmen participated in our research were informed about the study. Also, each sportsman was required to sign an acknowledgement of voluntarily participation under these conditions. The ethical board decision numbered 2010/30 and dated 06.10.2010 was made by the School of Physical Education and Sports in Selcuk University.

All sportsmen involved in the research were examined at the Selcuklu Medicine Faculty Hospital in Selcuk University. The sportsmen' blood analyses were carried out, their EKG and chest x-rays were taken, and the sportsmen who were not appropriate for the study, were excluded. The measurements were done in a laboratory environment at certain times and completed in 60 days. Providing that the relevant parameters analyzed were not affected during the study, the sportsmen involved in the research were required to comply with the normal traning and nutrition programs. The sportsmen were subjected to the blood analyses three times $\left(0^{\text {th }}\right.$ day, $30^{\text {th }}$ day, $60^{\text {th }}$ day) from the starting day of the research.

\section{Method}

24 basketball players participated in the research were classified into the groups including an experimental group of 12 ones and a control group of 12 ones. The control group only followed the training and nutrition programs without taking them any agent. But the experimental group was given a colostrum capsule (one capsule of $250 \mathrm{mg}$ in a day) 2 hours after breakfast, and water of 250-350 $\mathrm{ml}$ was provided them to drink. The colostrum capsules were ones produced by the GNC firm.

The amounts of immunoglobulins G, M, A, E were determined with the nefalometric method at the BN-Prospec-Simens device in the central microbiology laboratory of the Selcuklu Medicine Faculty. Total Protein, Albumin, Globulin levels were estimated with the spectrophotometric method at the Beckman Coulter LX20 autoanalyser.

\section{Statistical Analysis}

In estimation of data, the SPSS 15 statistical package program was used. The two-factor (timegroup; 3x2) variance analysis was done in the repetitive measurements after Bonferroni was arranged about if the measured variables of the study differ in basketball players among the experimental and control groups for the first, second and third times. When an important effect was found in the time factor, the one-factor variance analysis was applied in the repetitive measurements in order to determine whichever group this effect resulted from. The Bonferroni multiple comparison test was performed to analyze which measurement time the difference resulted from in the variables the important changes were observed in. When the Group $x$ the Time were in interaction or the group factor became more significant, the difference between the experimental and control groups in the measurement times was analyzed with the t-test in independent groups (1).

\section{RESULTS}

The effect of bovine colostrum usage on serum immunoglobulins and proteins in basketball players involved in the study was shown at Table 1.

\section{DISCUSSION}

This study was done to investigate the effect of bovine colostrum usage on immunoglobulins, minerals, vitamin levels and body compositions in basketball players.

Depending on the bovine colostrum usage within the research, it was found that the average serum IgG amounts increased among all sportsmen in time. And it was seen that there was no difference in the serum IgG between the experimental and control groups (Table 1). Researches showed that the colostrum supplement had no effect on IgG levels in athletes $(14)$, sportsmen $(7,15)$ and swimmers $(10)$. They informed that the serum IgG levels were between 6.5-16.0 g/L in adult persons (3). 
Table 1. The effect of bovine colostrum on serum immunoglobulin and protein levels in basketball players.

\begin{tabular}{|c|c|c|c|c|c|c|c|c|c|c|c|c|c|c|c|c|c|c|c|}
\hline & & \multicolumn{5}{|c|}{$1^{\text {st }}$ Measurement } & \multicolumn{5}{|c|}{$2^{\text {nd }}$ Measurement } & \multicolumn{5}{|c|}{$3^{\text {rd }}$ Measurement } & \multicolumn{3}{|c|}{ F } \\
\hline & & Mean & \pm & SEM & Min & Max & Mean & \pm & SEM & Min & Max & Mean & \pm & SEM & Min & Maks & Time & Group & $\begin{array}{c}\text { Group } \\
\times \\
\text { Time }\end{array}$ \\
\hline \multirow{2}{*}{$\begin{array}{l}\operatorname{Ig~G} \\
(\mathrm{g} / \mathrm{L})\end{array}$} & $\mathrm{BE}$ & 9.11 & \pm & $0.48^{\mathrm{a}}$ & 6.21 & 11.50 & 9.12 & \pm & $0.44^{\mathrm{a}}$ & 6.51 & 12.00 & 10.31 & \pm & $0.54^{\mathrm{b}}$ & 6.09 & 13.10 & \multirow{2}{*}{$15.72^{* *}$} & \multirow{2}{*}{0.01} & \multirow{2}{*}{0.55} \\
\hline & BC & 8.79 & \pm & $0.31^{\text {a }}$ & 7.27 & 10.80 & 9.33 & \pm & $0.31^{b}$ & 7.22 & 10.70 & 10.24 & \pm & $0.65^{a, b}$ & 8.47 & 16.70 & & & \\
\hline \multirow{2}{*}{$\begin{array}{l}\operatorname{Ig} A \\
(\mathrm{~g} / \mathrm{L})\end{array}$} & $\mathrm{BE}$ & 1.68 & \pm & $0.21^{\text {a }}$ & 0.94 & 3.21 & 1.75 & \pm & $0.21^{a, b}$ & 1.11 & 3.44 & 1.88 & \pm & $0.22^{\mathrm{b}}$ & 1.14 & 3.45 & \multirow{2}{*}{$4.07^{*}$} & \multirow{2}{*}{0.52} & \multirow{2}{*}{2.44} \\
\hline & BC & 1.54 & \pm & 0.12 & 0.80 & 2.13 & 1.65 & \pm & 0.13 & 0.82 & 2.22 & 1.59 & \pm & 0.15 & 0.77 & 2.50 & & & \\
\hline \multirow{2}{*}{$\begin{array}{l}\operatorname{Ig~M} \\
(\mathrm{g} / \mathrm{L})\end{array}$} & $\mathrm{BE}$ & 0.93 & \pm & $0.12^{\mathrm{a}}$ & 0.50 & 1.94 & 0.85 & \pm & $0.11^{b}$ & 0.43 & 1.79 & 0.85 & \pm & $0.12^{\mathrm{b}}$ & 0.44 & 1.85 & \multirow{2}{*}{$7.16^{* *}$} & \multirow{2}{*}{2.09} & \multirow{2}{*}{0.21} \\
\hline & BC & 1.20 & \pm & 0.16 & 0.66 & 2.53 & 1.11 & \pm & 0.14 & 0.57 & 2.41 & 1.14 & \pm & 0.15 & 0.56 & 2.21 & & & \\
\hline \multirow{2}{*}{$\begin{array}{c}\mathrm{Ig} \mathrm{E} \\
(\mathrm{IU} / \mathrm{ml})\end{array}$} & $\mathrm{BE}$ & 31.98 & \pm & $6.14^{a}$ & 15.30 & 83.20 & 37.45 & \pm & $6.52^{b}$ & 15.30 & 90.30 & 41.98 & \pm & $5.77^{b}$ & 15.30 & 82.50 & \multirow{2}{*}{$7.19^{* *}$} & \multirow{2}{*}{0.19} & \multirow{2}{*}{2.75} \\
\hline & $B C$ & 32.39 & \pm & 4.69 & 15.30 & 58.20 & 34.05 & \pm & 5.65 & 15.30 & 70.40 & 34.73 & \pm & 5.53 & 15.30 & 58.50 & & & \\
\hline \multirow{2}{*}{$\begin{array}{l}\text { Albumin } \\
(\mathrm{g} / \mathrm{dL})\end{array}$} & $\mathrm{BE}$ & 4.26 & \pm & 0.08 & 3.60 & 4.70 & 4.30 & \pm & 0.06 & 3.90 & 4.70 & 4.21 & \pm & 0.06 & 3.80 & 4.50 & \multirow{2}{*}{1.69} & \multirow{2}{*}{2.94} & \multirow{2}{*}{1.18} \\
\hline & BC & 4.47 & \pm & 0.07 & 4.10 & 4.80 & 4.37 & \pm & 0.06 & 4.00 & 4.70 & 4.35 & \pm & 0.07 & 3.70 & 4.60 & & & \\
\hline \multirow{2}{*}{$\begin{array}{c}\text { Globulin } \\
\text { (g/dL) }\end{array}$} & $\mathrm{BE}$ & 2.53 & \pm & $0.11^{\mathrm{a}}$ & 2.10 & 3.20 & 2.94 & \pm & $0.10^{b}$ & 2.40 & 3.50 & 2.95 & \pm & $0.09^{b}$ & 2.50 & 3.50 & \multirow{2}{*}{$12.10^{* *}$} & \multirow{2}{*}{0.01} & \multirow{2}{*}{$7.36^{*}$} \\
\hline & BC & 2.78 & \pm & 0.10 & 2.20 & 3.20 & 2.88 & \pm & 0.06 & 2.60 & 3.20 & 2.79 & \pm & 0.07 & 2.40 & 3.20 & & & \\
\hline \multirow{2}{*}{$\begin{array}{l}\text { Total Protein } \\
(\mathrm{g} / \mathrm{dL})\end{array}$} & $\mathrm{BE}$ & 6.79 & \pm & $0.18^{\mathrm{a}}$ & 5.70 & 7.60 & 7.24 & \pm & $0.14^{b}$ & 6.70 & 8.10 & 7.16 & \pm & $0.13^{a, b}$ & 6.50 & 7.80 & \multirow{2}{*}{2.91} & \multirow{2}{*}{0.96} & $390^{*}$ \\
\hline & BC & 7.25 & \pm & 0.14 & 6.60 & 8.00 & 7.25 & \pm & 0.10 & 6.60 & 7.80 & 7.16 & \pm & 0.12 & 6.10 & 7.60 & & & \\
\hline
\end{tabular}

${ }^{*} \mathrm{P}<0.05 ;{ }^{* *} \mathrm{P}<0.01$; the significant effect of group or time factors in group $\times$ time interaction (two-factor variance analysis in repetitive measurements). $\# \mathrm{P}<0.05$; the significant difference between the experimental and control groups for the 1 st, 2 nd and 3 rd measurements ( $t$-test in independent groups). $\mathrm{a}, \mathrm{b} \mathrm{P}<0.05$; the difference between averages carrying different letters at the same line is significant.

$\mathrm{BE}=$ Basketball Experimental Group $(\mathrm{n}=12), \mathrm{BC}=$ Basketball Control Group $(\mathrm{n}=12)$.

It was observed that the average amount of serum IgA was $1.68 \pm 0.21 \mathrm{~g} / \mathrm{L}$ for the $1^{\text {st }}$ measurement and $1.88 \pm 0.22 \mathrm{~g} / \mathrm{L}$ for the last measurement in the experimental group (Table 1). It was made clear that colostrum supplement increased the average amounts of serum IgA in experimental groups in time, and this increase was very significant $(\mathrm{P}<0.05)$. However, it was seen that there were no differences in $\operatorname{IgA}$ between the experimental and control groups (Table 1). Similar results $(10,14,15)$ were obtained from some sports branches. But (7) the average values of serum IgA were estimated to be higher than the values mentioned in this research. (3) Suggest that the average amount of serum $\operatorname{Ig} \mathrm{A}$ is between 1.0-4.0 $\mathrm{g} / \mathrm{L}$ in adults, these values comply with the average amounts of serum $\operatorname{Ig} \mathrm{A}$ in the research.

When examined the average serum IgM amounts, it was seen that the average amounts of serum IgM reduced. This decrease was observed to be significant at the level of $\mathrm{P}<0.01$. But no differences were found between the experimental and control groups (Table 1). Similar results were confirmed by $(7,10)$ 's studies.

It was determined that the average serum $\operatorname{IgE}$ amounts increased due to the bovine colostrum supplement. In the experimental group, the average amount of serum $\operatorname{IgE}$ was $31.98 \pm 6.14 \mathrm{IU} / \mathrm{ml}$ for the $1^{\text {st }}$ measurement, $37.45 \pm 6.52 \mathrm{IU} / \mathrm{ml}$ for the $2^{\text {nd }}$ measurement and $41.98 \pm 5.77 \mathrm{IU} / \mathrm{ml}$ for the $3^{\text {rd }}$ measurement (Table 1 ). Any increase in the average amounts of serum $\operatorname{IgE}$ $(\mathrm{P}<0.01)$ due to the colostrum usage was significant. There were no differences between the experimental and control groups (Table 1). Similar results were confirmed by the researchers $(7,10)$. It was stated that the average amount of serum IgE was $0-100 \mathrm{IU} / \mathrm{mL}$ in adults (3). It was concluded that the serum IgE levels in the research were between normal limits.

The research indicated that the serum albumin levels had no differences between the experimental and control groups, and that there were no changes in their average amounts (Table 1). Similar results were given by (10) saying that the colostrum usage did not cause any differences in albumin amounts among swimmers. Here, the average amount of serum albumin was between 3.5$5.2 \mathrm{~g} / \mathrm{dL}$ in adults (3).

The research also showed that the bovine colostrum usage increased the average amounts of serum globulin in the sportsmen. The average serum globulin amount was $2.53 \pm 0.11 \mathrm{~g} / \mathrm{dL}$ for the $1^{\text {st }}$ measurement, $2.94 \pm 0.10 \mathrm{~g} / \mathrm{dL}$ for the $2^{\text {nd }}$ measurement and $2.95 \pm 0.09 \mathrm{~g} / \mathrm{dL}$ for the $3^{\text {rd }}$ measurement in the experimental group. Any change in the serum globulin level was considered to be significant in time $(\mathrm{P}<0.01)$. Some changes in the average amounts of serum globulin were meaningful between the experimental and control groups $(\mathrm{P}<0.05)$ (Table 1). Here, the average amount of serum globulin was between 2.3$3.5 \mathrm{~g} / \mathrm{dL}$ in adults (3).

Within this research, it was explained that the bovine colostrum supplement increased the average amounts of serum total protein in the sportsmen. The amount of serum total protein was $6.79 \pm 0.18 \mathrm{~g} / \mathrm{dL}$ for the $1^{\text {st }}$ measurement, $7.24 \pm 0.14 \mathrm{~g} / \mathrm{dL}$ for the $2^{\text {nd }}$ measurement and $7.16 \pm 0.13 \mathrm{~g} / \mathrm{dL}$ for the $3^{\text {rd }}$ measurement in the experimental group. While the serum total protein level increased in the experimental group, it reduced in the control group. The changes between the experimental and control groups 
were considered to be meaningful $(\mathrm{P}<0.05)$ (Table 1$)$. The serum total protein level was between $6.4-8.3 \mathrm{~g} / \mathrm{dL}$ (3). The serum total protein values from the research had normal limits.

These results and the studies mentioned above are considered to have differences due to the doses and times of colostrum usage, the various sports branches or the different food habits of the sportsmen involved in the research.

In conclusion; within this study, any increase was found in average amounts in terms of the $\operatorname{IgG}, \operatorname{IgE}$, Globulin, Total Protein parameters due to the usage of bovine colostrum. But a significant decrease was observed in terms of the serum IgM. It was determined that the colostrum usage gave rise to differences in the globulin amount and the total protein values between the experimental groups and the control groups at this level $(\mathrm{P}<0.05)$.

In conclusion, it was informed that researches on colostrum usage would be appropriate in different sports branches and various age groups considering especially criteria such as sportsmen' immunity, regeneration, performance. And it was thought that sportsmen would benefit from high characteristics of colostrum at a maximum level, so this would lead to success.

\section{ACKNOWLEDGEMENTS}

This study was supported by The Scientific Research Projects Coordination Unit of Selcuk University (Project number: 10102031). None of the authors of this paper has a financial or personal relationship with other people or commercial identity mentioned in our paper that might lead to a conflict of interest for any of the authors.

\section{REFERENCES}

1. Alpar R. Spor Bilimlerinde Uygulamalı İstatistik, 3. baskı, Nobel yayın dağıtım, Ankara, 2006; 221-230.

2. Antonio J, Sanders MS, Van Gammeren D. The effects of bovine colostrum supplementation on body composition and exercise performance in active men and women. Nutrition, 2001; 17: 243-247.

3. Aslan D. Tietz Klinik Kimyada Temel İlkeler. In: Burtis CA, Ashwood ER, editörler. Beşinci Baskıdan Çeviri, Ankara: Palme yayıncilık, 2005; 961-1027.

4. Bayarer M, Karagözlü C, Akbulut N. İnsan Beslenmesinde kolostrumun önemi ve kullanım olanakları. Harran University Journal of Faculty of Agriculture, 2006; 10(3/4): 1121.

5. Brinkworth GD, Buckley JD, Bourdon PC, Gulbin JP, David AZ. Oral bovine colostrum supplementation enhances buffer capacity but not rowing performance in elite female rowers. Int J sport Nutrition Exerc Metab, 2002; 12: 349-63.

6. Buckley JD. Bovine Colostrum: Does it Improve Athletic Performance. Nutrittion, 2002; 18(9): 776-777.

7. Carol A, Witkamp RF, Wichers HJ, Mensink M. Bovine colostrum supplementation's lack of effect on immune variables during short-term intense exercise in well-trained athletes. Int J of Sport Nut Exercise Metab, 2011; 135-145.
8. Coombes J, Conacher M, Austen S, Marshall P. Dose effects of oral bovine colostrum supplementation on physical work capacity in cyclists. Med Sci Sports Exercise, 2002; 34: 11841188.

9. Crooks CV, Wall CR, Cross ML, Rutherfurd-Markwick KJ. The effect of bovine colostrum supplementation on savilary $\operatorname{IgA}$ in distance runners. Int J Sport Nutr Exerc Metab, 2006; 16: 47-64.

10. Crooks C, Cross ML, Wall C, Ali A. Effect of Bovine Colostrum Supplementation on Respiratory Tract Mucosal Defenses in Swimmers. Int $\mathrm{J}$ of Sport Nut and Exercise Metabolism, 2010; 20: 224-235.

11. Henderson DR, Mitchell D. Colostrum. CNR Publications ISBN-9676514-0-9 Sedona, AZ, USA. 2000; 54.

12. Hofman Z, Smeets R, Verlaan G, Lugt R, Verstappen PA. The effect of bovine colostrum supplementation on exercise performance in elite field hockey players. Int J Sport Nut Exerc Metab, 2002; 12: 461-469.

13. Kuipers H, van Breda E, Verlaan G, Smeets R. Effects of oral bovine colostrum supplementation on serum insulinlike growth factor-I levels. Nutrition, 2002; 18(7/8): 566-567.

14. Mero A, Miikkulainen H, Riski J, Pakkanen R, Aalto J, Takala T. Effects of bovine colostrum supplementation on serum IGF-I, IgG, hormone, and saliva IgA during training. J Appl Physiol, 1997; 83(4): 1144-51.

15. Mero A, Kahkönen J, Nykanen T, Parviainen T, Jokinen I, Takala T, Nikula T, Rasi S, Leppaluoto J. IGF-1, IgA, and IgG responses to bovine colostrum supplementation during training. J Appl Physiol, 2002; 93: 732-739.

16. Shing CM, Jenkins DG, Stevenson L, Coombes JS. The influence of bovine colostrum supplementation on exercise performance in highly-trained cyclists. Br J Sports Med, 2006; 40: 797-801.

17. Shing CM, Peake J, Suzuki K, Okutsu M, Pereira R, Stevenson L, Jenkins DG, Coombes JS. Effects of bovine colostrum supplementation on immune variables in highly trained cyclists. J Appl Physiol, 2007; 102: 1113-1122.

18. Thapa BR. Health factors in colostrum. Indian Journal of Pediatrics, 2005; 72(7): 579-581. 